E ISSN : $2302-1810$

DOI : doi.org/1021009/wahana-akuntansi/12.1.03

\title{
PENGARUH PERSEPSI DAN MOTIVASI TERHADAP MINAT BERKARIR MAHASISWA DI BIDANG PERPAJAKAN JURUSAN AKUNTANSI FAKULTAS EKONOMI PADA UNIVERSITAS NEGERI JAKARTA
}

\author{
Lisa Rachmawati \\ Indra Pahala \\ Tresno Eka Jaya \\ Email : pahala.indra@gmail.com
}

Fakultas Ekonomi Universitas Negeri Jakarta

\begin{abstract}
This study aimed to determine the effect of perception and motivation to Students Career Interests in Taxation of Departement of Accounting Faculty of Economics at the State University of Jakarta.

This study used 75 students 1 Departement of Accounting, State University of Jakarta which is still active academic year 2010. Data used in this study is primary data and selection of samples using a convenience sampling method. The analytical tool used is multiple linear regression analysis at a significance level of 5\%. The first phase of testing the validity and reliability of the statement of each variable. The second stage, performing variable regression perception and motivation towards a career in the field of taxation the interest of students.

The results of testing the feasibility of the model shows that the two independent variables, namely perception and motivation affect the career interests of students in the field of taxation Accounting Department of Economics at the State University of Jakarta simultaneously.
\end{abstract}

Keywords: perception, motivation, and career interest in the field of taxation.

\section{PENDAHULUAN}

Pendidikan adalah salah satu bentuk perwujudan seni dan budaya manusia yang dinamis dan syarat akan perkembangan. Pemikiran ini mengandung konsekwensi bahwa penyempurnaan atau perbaikan

pendidikan kejurusan untuk Jurnal IImiah Wahana Akuntansi

\begin{abstract}
mengantisipasi kebutuhan dan tantangan masa depan perlu terus menerus dilakukan penyelarasan perkembangan kebutuhan dunia usaha kerja, perkembangan ilmu pengetahuan, teknologi, seni dan budaya.
\end{abstract}

Peningkatan pertumbuhan ekonomi yang pesat saat ini harus diimbangi 
E ISSN : $2302-1810$

DOI: doi.org/1021009/wahana-akuntansi/12.1.03

dengan jumlah tenaga kerja yang pengetahuan mahasiswa, terutama tentang berkualitas sehingga akan tercapai kondisi perekonomian jumlah tenaga kerja yang berkualitas dan akan tercapai kondisi perekonomian yang kondusif. Kondisi yang demikian ini diperlukan investasi pada sumber daya manusia untuk melanjutkan proses industrialisasi serta dapat membawa perekonomian yang senantiasa tumbuh dan berkembang. Disamping itu juga diperlukan sarana dan prasarana non fisik yang sangat ditentukan oleh pengembangan kualitas sumber daya manusia. Hal tersebut tampak dengan terabaikannya prioritas pengembangan sumber daya manusia, yang kadang kala berkembang sebagaimana sering terjadi dalam dunia mode yaitu berkembang mengikuti trend yang ditunjukkan dengan banyak ditemukan lembagalembaga pendidikan yang didukung oleh fasilitas yang sangat minimal, yang masih jauh dari memadai untuk menciptakan sumber daya manusia yang berkualitas. Terbukti

masih banyak ketidakmerataan pengetahuan mahasiswa tentang prospek masa depan mahasiswa di karir profesi, dan pekerjaan yang beruhubungan dengan program studi perpajakan, membuat mahasiswa tidak mampu memaksimalkan potensinya selama mengikuti kegiatan dari kampus untuk dijadikan bekal kelak ketika terjun didunia kerja.

Kesempatan pendidikan yang semakin meluas di negara-negara yang sedang berkembang termasuk Indonesia, telah mempengaruhi pasar tenaga kerja. Perubahanperubahan yang terjadi terhadap pemintaan tenaga kerja sesuai bidang yang dibutuhkan

dalam dunia kerja membawa perubahan dan pembaharuan dalam kesempatan pendidikan. Dengan adanya Jurusan Akuntansi kosentrasi perpajakan, maka mahasiswa memperoleh dua ilmu sekaligus yaitu Ilmu Akuntansi dan Ilmu Perpajakan yang setara Brevet A dan B. Kedua ilmu tersebut sangat berkaitan karena perhitungan pajak tidak akan terlepas dari perhitungan akuntansi dan begitu pula sebaliknya. Perusahaan akan lebih cenderung memilih lulusan yang dunia perpajakan. Minimnya

Jurnal IImiah Wahana Akuntansi

Volume 12 No.01, Tahun 2017 
memiliki kedua ilmu tersebut daripada merekrut dua tenaga kerja dengan dua jurusan yang berbeda karena akan menghemat biaya dan akan lebih cepat pekerjaannya.

Begitu banyak pilihan karir yang dihadapkan bagi mahasiswa lulusan akuntansi menjadi sulit mengambil keputusan dalam memilih. Hal itu akan mengembalikan pertanyaan-pertanyaan seputar pemilihan profesi kepada mahasiswa itu sendiri,

apakah yang menjadi latar belakang pemilihannya itu, sehingga kondisi tersebut mengakibatkan bahwa tidal terjaminnya bahwa mahasiswa akuntansi memilih profesi karirnya sebagai akuntan baik itu akuntan publik atau non publik. Perencanaan karir merupakan satu hal yang sangat penting untuk mencapai kesuksesan dalam karir. Akan tetapi, sebagian orang tidak dapat melakukan perencanaan karir secara tepat karena senantiasa dihinggapi kekhawatiran terhadap ketidakpastian dimasa datang.

Pilihan karir yang ada saat ini diharapkan akan menjadikan seseorang menjadi profesional dalam bidangnya masing-masing sehingga karir yang diinginkan akan tercapai sesuai dengan harapannya. Dalam penelitian tersebut didapat hasil bahwa secara simultan atau bersama-sama variabel persepsi berpengaruh secara signifikan terhadap minat berprofesi sebagai akuntan publik. Perbedaan dalam penelitian ini adalah penambahan variabel independen motivasi dan merubah variabel dependen yaitu minat berkarir di bidang pajak.

Berdasarkan latar belakang tersebut, penulis bermaksud mengadakan penelitian mengenai "pengaruh persepsi dan motivasi terhadap minat berkarir mahasiswa dibidang perpajakan Jurusan Akuntansi Fakultas Ekonomi pada Universitas Negeri Jakarta"

\section{KAJIAN TEORETIK \\ Persepsi}

Menurut Robbins (1996) mengemukakan bahwa persepsi berkarir jika individu merasa organisasi tempatnya bekerja menyediakan peluang bagi dirinya untuk dapat memenuhi kebutuhan dan tujuan karirnya maka individu yang bersangkutan akan membentuk persepsi yang positif

Jurnal IImiah Wahana Akuntansi

Volume 12 No.01, Tahun 2017 
E ISSN : $2302-1810$

DOI: doi.org/1021009/wahana-akuntansi/12.1.03

mengenai pengembangan karirnya dalam organisasi tersebut. Sebaliknya, jika individu merasa organisasi

tempatnya bekerja kurang menyediakan peluang bagi dirinya untuk dapat memenuhi kebutuhan dan tujuan karirnya maka individu yang bersangkutan akan membentuk persepsi yang negatif mengenai

pengembangan karirnya dalam organisasi tersebut. Persepsi berkarir adalah tanggapan seseorang dalam memahami apa yang ada disekitarnya dalam berkarir, termasuk dalam hal ini adalah lingkungan berupa objek, orang, atau simbol tertentu. Persepsi bertujuan memberikan makna terhadap hal-hal tersebut melalui panca indra berdasarkan yang didapat dari lingkungannya dalam meniti karir yang akan mereka tempuh kedepannya. Persepsi dan penilaian seseorang terhadap sesuatu hal akan dipengaruhi secara signifikan oleh asumsi-asumsi (stimulus) yang kita buat tentang suatu hal tersebut. Setiap orang dapat memilih berbagai petunjuk yang mempengaruhi persepsinya atas objek, orang dan simbol. Maka dari itu, persepsi masing-masing individu Jurnal IImiah Wahana Akuntansi terhadap suatu hal tidak selalu sama, bahkan bisa berbeda.

\section{Sarlito W Sarwono (2010:86)}

mengemukakan bahwa persepsi berlangsung saat seseorang menerima stimulasi dari dunia luar yang ditangkap oleh organ-organ bantuannya yang kemudian masuk kedalam otak. Didalamnya terjadi proses berpikir yang pada akhirnya terwujud dalam sebuah pemahaman. Pemahaman ini yang disebut persepsi.

Sebelum terjadinya persepsi pada manusia, diperlukan sebuah stimulasi yang harus ditangkap melalui organ tubuh yang bisa digunakan

sebagai alat bantunya untuk memahami lingkungannya. Alat bantu ini dinamakan alat indra. Indra yang saat ini secara universal diketahui adalah hidung, mata, telinga, lidah dan kulit.

${ }^{\text {Motivasi }}{ }_{\text {Menurut Ibriati Kartika Alimuddin }}$ (2012) motivasi dalam berkarir yaitu motivasi tingkat tertinggi yang dimiliki seseorang yang dijadikan dasar dalam mengambil setiap tindakan yang berkaitan dengan karirnya. Ketika 
E ISSN : $2302-1810$

DOI: doi.org/1021009/wahana-akuntansi/12.1.03

seorang pegawai telah memiliki motivasi aktualisasi diri dalam berkarir, maka ia akan mengerahkan segala potensi yang dimilikinya untuk dapat menyelesaikan pekerjaannya. Bukan materi yang dicarinya, melainkan kepuasan batin akan prestasi yang telah diraihnya.

Menurut Sardiman (2012) motivasi berawal dari kata motif, motif tersebut dapat diartikan sebagai daya upaya yang mendorong seseorang untuk melakukan sesuatu. Motif dapat dikatakan sebagai daya penggerak dari dalam dan didalam subjek untuk melakukan aktivitasaktivitas tertentu demi mencapai suatu tujuan. Bahkan motif dapat diartikan sebagai suatu kondisi intern (kesiapsiagaan), maka motivasi dapat diartikan sebagai daya penggerak yang telah menjadi aktif. Motif menjadi aktif pada sa at tertentu, te rutam a b ila kebutuhan untuk $m$ enc apa $i$ tujuan $s$ angat dirasakan/mendesak.

\section{Minat}

Menurut Suryobroto (1998: 109) dalam Ardyansyah minat adalah kecendrungan dalam diri individu untuk Jurnal IImiah Wahana Akuntansi tertarik pada suatu objek. Timbulnya minat terhadap suatu objek ini ditandai dengan adanya rasa senang atau tertarik.

Berdasarkan definisi diatas minat berkarir adalah suatu pemusatan yang tidak di sengaja yang terlahir dari dalam diri individu untuk mengerti individu dan menuntun aktivitas dimasa yang akan datang. Minat berkarir di dalam bidang pajak banyak dibutuhkan dikarenakan Dirjen Perpajakan RI telah memperketat penerapan. Kebutuhan peraturan perpajakan Indonesia dan banyaknya kasus perpajakan yang melibatkan berbagai perusahaan saat ini semakin memperbaiki kinerja yang dimiliki dengan mencari tenaga kerja ahli yang tidak hanya mengerti tentang akuntansi juga memahami pehitungan

pajak sehingga memperbanyak peluang profesi dibidang perpajakan. Karir di bidang perpajakan seperti konsultan pajak, pegawai Direktorat Jendral pajak, dosen pajak. Minat berkarir Suatu status atau jenjang pekerjaan atau jabatan seseorang sebagai sumber nafkah apakah itu sebagai pekerjaan utama maupun pekerjaan sambil. 
E ISSN : $2302-1810$

DOI: doi.org/1021009/wahana-akuntansi/12.1.03

Karir dibidang perpajakan

Menurut Santoso (1992) dalam Waluyo pajak adalah iuran kepada negara (yang dapat dipaksakan) yang terutang oleh yang wajib membayarnya menurut peraturanperaturan, dengan tidak mendapat prestasi kembali, yang langsung dapat ditunjuk, dan yang gunanya adalah untuk membiayai pengeluaran-pengeluaran umum berhubung dengan tugas negara yang menyelenggarakan pemerintahan.

Karir di bidang pajak ini sangat terbuka lebar bagi calon pegawai pajak. Negara indonesia membutuhkan orang yang bisa membuat dan mengelola sistem perpajakan yang baik dan kalangan swasta membutuhkan orang yang mampu menangani hak dan kewajiban pajak perusahaan dengan baik sehingga akan tumbuh profesiprofesi penunjang seperti konsultan pajak, pengajar pajak, dan sebagainya yang banyak dibutuhkan.

Selain hal tersebut kebutuhan akan karir di dalam bidang pajak banyak dibutuhkan dikarenakan

Dirjen Perpajakan RI telah memperketat penerapan. Kebutuhan peraturan perpajakan Indonesia dan banyaknya kasus perpajakan yang melibatkan berbagai perusahaan saat ini semakin memperbaiki kinerja yang dimiliki dengan mencari tenaga kerja ahli yang tidak hanya mengerti tentang akuntansi juga memahami pehitungan pajak sehingga memperbanyak peluang profesi dibidang perpajakan. Beberapa profesi yang berhubungan dengan disiplin ilmu perpajakan, yaitu pegawai Direktorat Jendral pajak, konsultan pajak dan tax specialist.

\section{Pengembangan Hipotesis}

Berdasarkan rumusan masalah dan landasan teori yang telah diuraikan diatas, maka variabel dependen yang digunakan pada penelitian ini yaitu minat berkarir dib id ang perpajakan pada mahasiswa jurusan Akuntansi fakultas Ekonom i Universitas Negeri Jakarta. Variabel independent pada penelitian ini adalah persepsi dan motivasi. Berdasarkan penjelasan diatas, kerangka konseptual.

Kerangka pemikiran dalam penelitian ini dapat digambarkan sebagai berikut: 
E ISSN : $2302-1810$

DOI: doi.org/1021009/wahana-akuntansi/12.1.03

\section{Gambar: kerangka Konseptual Penelitian}

\section{METODOLOGI PENELITIAN}

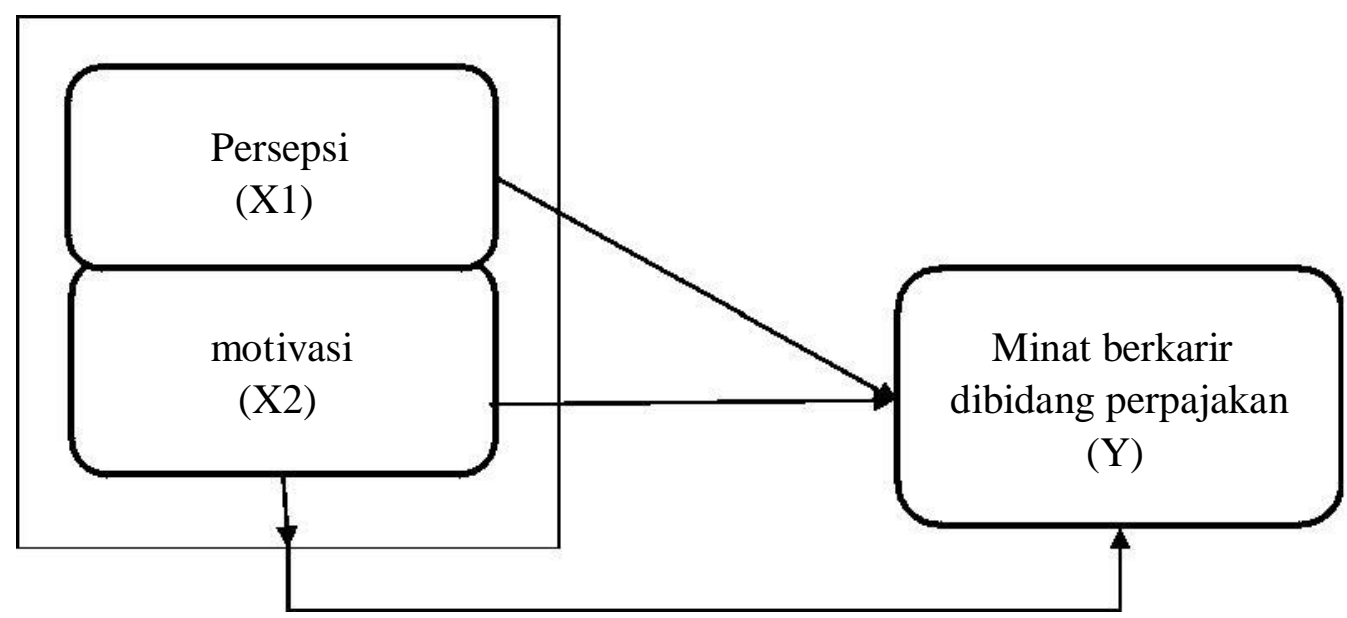

$\mathrm{H} 1$ : Terdapat pengaruh antara

persepsi terhadap minat mahasiswa

Jurusan Akuntansi Fakultas Ekonomi

Universitas Negeri Jakarta berkarir di

bidang perpajakan.

$\mathrm{H} 2$ : Terdapat pengaruh antara

motivasi terhadap minat mahasiswa

Jurusan Akuntansi Fakultas Ekonomi

Universitas Negeri Jakarta berkarir di

bidang perpajakan.

H3 : Terdapat pengaruh persepsi dan motivasi secara simultan terhadap minat mahasiswa Jurusan Akuntansi Fakultas Ekonomi Universitas Negeri Jakarta berkarir di bidang perpajakan.
Populasi dari penelitian ini adalah Mahasiswa Jurusan Akuntansi Fakultas Ekonomi pada Universitas Negeri Jakarta pada tingkat semester akhir yang ingin melakukan berkarir. Dalam penelitian ini adalah dengan menggunakan Non Probability Sampling yang mendasarkan pada seluruh anggota populasi tidak memiliki kesempatan yang sama untuk dipilih menjadi sampel. Digunakan tingkat kelonggaran ketidaktelitian $10 \%$. Jenis dan sumber data yang digunakan dalam penelitian ini adalah data primer berupa kuesioner yang diisi oleh mahasiswa sebagai

Jurnal IImiah Wahana Akuntansi 
E ISSN : $2302-1810$

DOI: doi.org/1021009/wahana-akuntansi/12.1.03

responden.Jawaban responden yang diperoleh saat melakukan pengisian kuesioner diukur dengan menggunakan skala Likert.

\section{Definisi Operasional Variabel}

Persepsi berkarir dapat diukur dengan memberikan nilai 1 sampai dengan 5 pada setiap jawaban dari pertanyaan yang diajukan kepada responden. Dalam Muham madinah Dalam Mei Trisnawati.K (2012), perspsi diukur dengan menggunakan

indikator proses perkuliahan, pengetahuan bermanfaat, pelatihan A B Brevet, kemampuan analitis, kemampuan interpersonal.

Motivasi berkarir dapat diukur dengan menggunakan skala likert dengan nilai 1 sampai 5. Motivasi berkarir dinilai dengan indikator yang digunakan dalam Muhammad Ikbal (2011) yaitu keinginan, keahlian aplikasi pengetahuan, kemampuan prestasi, gaji tambahan yang tinggi, peran dan tanggung jawab.

Minat berkarir dapat diukur dengan menggunakan skala likert dengan nilai
1 sam pai $5, \mathrm{~m}$ in at berkarir din ilai dengan in dikator y ang digunakan dalam Muhammadinah (2009) yaitu peluang, pengalaman dan pengetahuan, gaji yang besar, fasilitas memadai.

\section{Teknik Analisis Data}

Pada penelitian ini umumnya variabel yang tidak dapat diukur secara langsung, tetapi dibentuk melalui dimensi-dimensi yang diamati atau

indikator-indikator yang diamati. Biasanya indikator yang diteliti dengan menggunakan kuesioner bertujuan untuk mengetahui pendapat responden tentang suatu hal. Skala yang sering dipakai dalam penyusunan kuesioner adalah skala ordinal atau sering disebut skala likert.

\section{PEMBAHASAN}

Hasil yang didapat dari penelitian ini dengan melibatkan 75 orang mahasiswa yang berkarir dibidang perpajakan pada universitas negeri jakarta sebagai responden adalah 1) persepsi berkarir dibidang perpajakan berpengaruh terhadap minat berkarir mahasiswa dib idang perpajakan , 2) 
E ISSN : $2302-1810$

DOI: doi.org/1021009/wahana-akuntansi/12.1.03

motivasi berkarir dibidang perpajakan berpengaruh terhadap minat berkarir dibidang perpajakan pada universitas negeri jakarta. Dalam penelitian ini, mencakup tiga variabel. Variabel independen terdiri dari persepsi berkarir dan motivasi berkarir. Variabel dependen yaitu minat berkarir mahasiswa dibidang perpajakan.

Tabel 1. $R$ Square

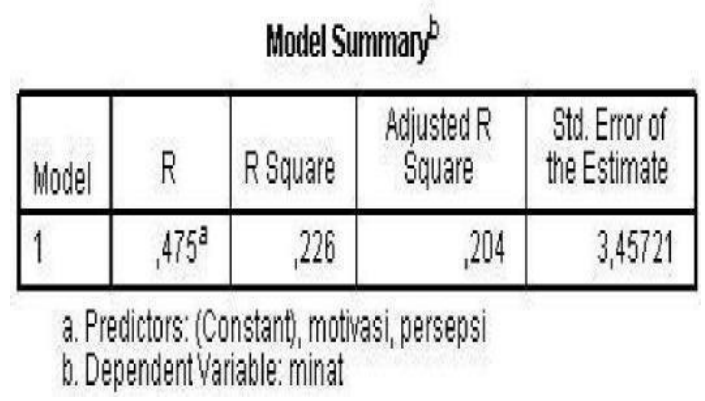

Berdasarkan hasil perhitungan estimasi regresi, diperoleh nilai Adjusted R Square sebesar 20,4\% yang berarti variabel persepsi dan motivasi berpengaruh terhadap minat berkarir mahasiswa akuntansi dibidang perpajakan. Kedua variabel independen tersebut mampu menjelaskan variabilitas variabel dependen sebesar 20,4\% sedangkan sisanya 79,6\% yaitu sebesar dijelaskan variabel lain yang tidak dimasukkan ke dalam model regresi.

Jurnal IImiah Wahana Akuntansi

Volume 12 No.01, Tahun 2017 
E ISSN : $2302-1810$

DOI: doi.org/1021009/wahana-akuntansi/12.1.03

Pengaruh persepsi berkarir dibidang perpajakan berpengaruh terhadap minat berkarir $\mathrm{m}$ ahasiswa dib id ang perpajakan pada Universitas Negeri Jakarta. Berdasarkan hasil uji-t maka dapat dilihat bahwa nilai t hitung sebesar 3,354 pada tingkat signifikan 0,01 dan t tabel 1,993, hal ini berarti ada hubungan antara variabel independen dan variabel dependen. Dan dapat disimpulkan bahwa hipotesis pertama (H1) dalam penelitian ini diterima.

Pengaruh motivasi berkarir terhadap minat berkarir mahasiswa dibidang perpajakan pada Universitas Negeri Jakarta. Berdasarkan hasil uji-t yang disajikan dalam tabel 4.14 maka dapat dilihat bahwa nilai $\mathrm{t}$ hitung nilai $\mathrm{t}$ hitung 2,323 pada tingkat signifikan 0,023 dan t tabel 1,993 jadi $\mathrm{H}_{2}$ diterima, hal ini berarti ada hubungan yang signifikan antara variabel independen dan variabel dependen. Dan dapat disimpulkan bahwa hipotesis kedua (H2) dalam penelitian ini diterima.

Pengaruh persepsi dan motivasi terhadap minat berkarir mahasiswa di bidang perpajakan Universitas Negeri Jakarta

Uji pengaruh simultan (F-test) sebesar 10,488 dan signifikansi sebesar 0,000 dengan demikian $\mathrm{H}_{0}$ ditolak dan $\mathrm{H}_{\mathrm{a}}$ diterima, nilai ini menunjukkan bahwa variabel independen yaitu persepsi berkarir dan motivasi berkarir mempengaruhi variabel dependen yaitu minat berkarir mahasiswa dibidang perpajakan secara simultan. berarti model yang digunakan pada penelitian ini adalah layak.

\section{KESIMPULAN, IMPLIKASI DAN}

\section{SARAN Kesimpulan}

Berdasarkan hasil penelitian dan pembahasan yang telah dilakukan pada sebelumnya, maka dapat ditarik kesimpulan sebagai berikut:

1. Persepsi berkarir berpengaruh posistifpadaminatberkarir 
mahasiswa dibidang perpajakan. Hal ini terjadi semakin tinggi persepsi berkarir maka semakin tinggi minat mahasiswa dibidang perpajakan pada Universitas Negeri Jakarta dan sebaliknya apabila semakin rendah persepsi berkarir yang dilakukan mahasiswa dalam bidang perpajakan maka semakin rendah minat berkarir dibidang perpajakan pada Universitas Negeri Jakarta. Karena bahwa mahasiswa berkarir di bidang perpajakan akan meningkatkan kemampuan analitis untuk memecahkan masalah perpajakan dalam kehidpan sehari-hari.

2. motivasi berkarir terhadap minat berkarir mahasiswa dibidang perpajakan berpengaruh positif. Hal ini dikarenakan semakin tinggi motivasi berkarir maka semakin tinggi minat berkarir mahasiswa pada bidang, sebaliknya apabila semakin rendah motivasi berkarir maka semakin rendah juga minat berkarir mahasiswa pada bidang perpajakan. Setiap mahasiswa bermotivasi bahwa ingin mendapatkan sesuai dengan latar belakang pendidikan yang mereka tempuh selama perkuliahan.

3. Persepsi dan motivasi berkarir terhadap minat berkarir mahasiswa di bidang perpajakan secara simultan layak didalam penelitian ini. Dalam pernyataan minat berkarir bahwa karir di bidang perpajakan memberikan peluang yang besar bagi mahasiswa Akuntansi.

4. Kasus Pajak di Indonesia menduduki peringkat kedua setelah kasus korupsi yang sedang mewabah di semua kalangan saat ini. Dari sejak dahulu, Departemen yang satu ini memang terkenal sarat dengan permainan antara para pegawai yang terkait dengan para wajib pajak sehingga menyebabkan berkurangnya rasa percaya masyarakat terhadap departemen ini atau bahkan sudah menjalar ke rasa tidak percaya kepada

pemerintah. Hal ini membuat masyarakat enggan untuk taat membayar pajak walaupun itu merupakan kewajiban sebagai warga negara yang baik. 
5. Fenomena pajak yang terjadi di Indonesia pun sangat beragam, mulai dari halhal yang termasuk kategori yang harus dibayar pajaknya sampai kasus-kasus besar yang mangkir dari membayar pajak. Padahal, bila dihitung nominal pajak yang tidak dibayarkan pajaknya sangatlah besar dan sangat membantu pemerintah di dalam mengalokasikan dana tersebut untuk membuat saranasarana yang notabene nya untuk rakyat itu sendiri. Tapi kembali lagi ke individu yang harus sadar akan pentingnya pajak dan hukum-hukum yang telah mengatur perpajakan di indonesia.

\section{Implikasi}

Ada beberapa implikasi dalam penelitian ini yaitu:

\section{Persepsi berkarir akan} meningkatkan minat berkarir jika individu merasa organisasi tempatnya berkarir menyediakan peluang bagi dirinya untuk dapat memenuhi kebutuhan dan tujuan karirnya maka individu yang bersangkutan akan membentuk persepsi yang positif mengenai pengembangan karirnya dalam organisasi tersebut. Maka dari itu, mahasiswa harus mengembangkan kemampuan dibidang perpajakan untuk berkarir dibidang perpajakan.

2. Motivasi berkarir akan meningkatkan minat berkarir jika individu telah memiliki motivasi aktualisasi diri dalam berkarir, maka akan mengerahkan segala potensi yang dimilikinya untuk dapat menyelesaikan pekerjaannya. Bukan materi yang dicarinya, melainkan kepuasan batin akan prestasi yang telah diraihnya.

\section{Saran}

Berdasarkan hasil penelitian, maka peneliti memiliki beberapa saran yang dapat disampaikan adalah sebagai berikut:

1. Jangka waktu penelitian yang cukup singkat menyebabkan peneliti kesulitan dalam mendapatkan data dari 
jumlah responden yang banyak. Dalam penelitian selanjutnya, pemilihan waktu penyebaran kuesioner lebih baik jangan pada saat sama sama sibuk dengan

perkuliahan. Pemilihan waktu penyebaran kuesioner lebih baik pada bulan

Januari-Februari, karena dalam waktu tersebut mahasiswa sedikit lebih santai dalam perkuliahannya

2. Sampel penelitian ini hanya mahasiswa akuntansi angkatan 2010, sehingga hasil penelitian ini belum mewakili seluruh mahasiswa pada jurusan akuntansi.Peneliti selanjutnya disarankan untuk memperluas jumlah mahasiswa penelitian hingga seluruh mahasiswa akuntansi atau mungkin dilakukan pada mahasiswa di universitas lain agar hasil penelitian nantinya dapat dibandingkan dengan

Jurnal Ilmiah Wahana Akuntansi penelitian-penelitian

sebelumnya.

3. Penelitian hanya menggunakan 2 variabel bebas yaitu persepsi dan motivasi. Akan lebih baik jika nantinya penelitian ini diperluas dengan menambah variable -variabel lainnya yang berhubungan dengan hal-hal yang mempengaruhi minat berkarir mahasiswa.

4. pajak di Indonesia masih harusditingkatkanlagi aturan-aturannya,demi menghindarikasus-kasus yang dapat merugikan negara. dan memberikan sanksi yang keras bagi para warga yang mangkir dari pajak. Dengan hal itu, diharapkan mereka dapat segera mematuhi dan membayarkan pajak tepat pada waktunya. Dan diharapkan juga, dengan kelancaran parawarganegara 
E ISSN : $2302-1810$

DOI: doi.org/1021009/wahana-akuntansi/12.1.03

Indonesia dapat

mensukseskan

pembangunan di Indonesia.

Dan lagi lagi peran pemerintah lah yang sangat diperlukan demi mewujudkan kesadaran akan pentingnya pajak itu sendiri.

\section{DAFTAR PUSTAKA}

Fikhri, Azhrul. 2010. Persepsi Mahasiswa Tentang Pendidikan Profesi Akuntansi (PPAk) studi empiris pada Universitas Islam Negeri dan Universitas Indonesia.

Ghozali, Imam. Aplikasi Analisis Multivariate Dengan Program Ibm SPSS 19. Semarang: Penerbit Badan Penerbit Universitas Diponegoro, 2011

M, Sardiman A. Interaksi dan Motivasi BelajarMengajar. Jakarta: Penerbit PT Raja Grafindo Persada, 2012

Makmun, Abin Syamsuddin. Psikologi Kependidikan. Bandung: Jurnal IImiah Wahana Akuntansi
Penerbit PT Remaja

Rosdakarya, 2009.

Muhammadinah, Effendi, Rahmad. 2009. Pengaruh Persepsi dan Minat Mahasiswa

Akuntansi Universitas

Bina Darma Palembang

terhadap Profesi Akuntan

Publik. Jurnal Riset

Akuntansi.

Mutia Ismail, Evi Lestari. 2012.

Pengaruh Motivasi

Terhadap Minat

Mahasiswa Akuntansi

untuk Mengikuti

Pendidikan Profesi

Akuntansi (PPAk) di

Perguruan Tinggi Sumetra

Utara.

Nanda Estie, Aris Eddy, Djoko

Kristianto. Pengaruh

Persepsi dan Lama

Pendidikan Terhadap

Minat Mahasiswa untuk

Mengikuti Pendid ikan

Profesi Akuntansi.

Nurdini, Bambang Haryadi, Anis

Wulandari. Pengaruh

Persepsi Mahasiswa

Akuntansi Terhadap

Minat Untuk Berprofesi 
E ISSN : $2302-1810$

DOI: doi.org/1021009/wahana-akuntansi/12.1.03

sebagai (Survey terhadap

Persepsi Mahasiswa

mahasiswa akuntansi se-

Akuntansi Dalam

Madura).

Sarwono, Sarlito W. Pengantar

Psikologi Umum, Jakarta:

Memilih Profesi Sebagai

Penerbit PT RajaGrafindo, 2010

Sugiyono, Metode Penelitian

Administrasi. Bandung: Penerbit

Alfabet, 2011

Sobur, Alex. Psikologi Umum.

Bandung: Pustaka Setia, 2003

Trisnawati, Mei. 2013. Pengaruh persepsi dan motivasi terhadap minat mahasiswa Jurusan Akuntansi Fakultas Ekonomi dan Bisnis Universitas Brawijaya berkarir dibidang perpajakan.

Walgito, B. Pengantar Psikologi Umum.

Yogyakarta: Andi Offset, 2004 Waluyo,

Perpajakan Indonesia. Jakarta: Penerbit

Salemba Empat, 2011

William Andersen. 2012. Analisis

Jurnal Ilmiah Wahana Akuntansi

Volume 12 No.01, Tahun 2017 